\title{
Antecedents and Consequences of Digital Entrepreneurial Ecosystems in the Interaction Process with Smart City Development
}

\author{
Irina Gorelova $^{1, *(\mathbb{D}}$, Diana Dmitrieva $^{2} \mathbb{D}$, Mariya Dedova $^{3}$ and Marco Savastano $^{1}(\mathbb{D}$ \\ 1 Department of Management, Sapienza University of Rome, 00161 Rome, Italy; marco.savastano@uniroma1.it \\ 2 Economics, Organization and Management Department, Saint Petersburg Mining University, \\ 199106 Saint Petersburg, Russia; diana-dmitrieva@mail.ru \\ 3 Department of Geography, University of Tartu, 51005 Tartu, Estonia; mariya.dedova@ut.ee \\ * Correspondence: irina.gorelova@uniroma1.it
}

check for updates

Citation: Gorelova, Irina, Diana Dmitrieva, Mariya Dedova, and Marco Savastano. 2021. Antecedents and Consequences of Digital Entrepreneurial Ecosystems in the Interaction Process with Smart City Development. Administrative Sciences 11: 94. https://doi.org/10.3390/ admsci11030094

Received: 29 July 2021

Accepted: 24 August 2021

Published: 6 September 2021

Publisher's Note: MDPI stays neutral with regard to jurisdictional claims in published maps and institutional affiliations.

Copyright: (c) 2021 by the authors. Licensee MDPI, Basel, Switzerland. This article is an open access article distributed under the terms and conditions of the Creative Commons Attribution (CC BY) license (https:// creativecommons.org/licenses/by/ $4.0 /)$.

\begin{abstract}
The nature of entrepreneurship and its developmental paths in the urban environment are extensively studied in the scientific literature. With a rising interest of scholars in the smart city phenomenon, the role entrepreneurship plays in the development of smart cities became a central topic in academia. However, there is a lack of discussion concerning the specific settings and characteristics of digital entrepreneurship in the smart city scenario. Nowadays, the concept of digital entrepreneurship is considered as a part of the digital entrepreneurial ecosystems (DEE) that provides an environment for effective entrepreneurial activities. Hence, the investigation on how DEE is interconnected with smart cities and how they both can contribute to their mutual development appears both timely and necessary. To reach this research objective, the authors, after giving a clear definition of each component of DEE based on an extensive literature review, consider its interconnection with the smart city model. The connection between the dimensions of a smart city and the structural constituents of DEE is also tracked, highlighting the contribution of each element to the development of a smart city. Through the creation of a comprehensive framework, the results of the paper show clearly that DEE is an inevitable part of a smart city environment. The research also covers the model of DEE engagement in smart city architecture.
\end{abstract}

Keywords: smart city; digital entrepreneurship; digital entrepreneurial ecosystem; smart city dimensions; digital transformation; collaborative economy

\section{Introduction}

Around $55 \%$ of the world population and $75 \%$ of the European population live in cities (World Bank 2019) and need access to better living conditions, as well as talent discovery and expression. By 2030, six out of every ten people are expected to live in a city, and by 2050 this number will increase to seven out of ten. The number of urban residents is growing by nearly 60 million people every year; as the world becomes more urban, cities need to become smarter (Manville et al. 2014). From the end of the 20th century, cities have been increasingly looking for solutions to traditional management challenges, environmental problems, as well as creating the necessary conditions to raise citizens' satisfaction and well-being. The phenomenon of Smart Cities (SC) took shape and has been evolving through the inclusion of various dimensions, from Information and Communication Technologies (ICTs) and infrastructure to social and human capital, in order to generate greater and more sustainable economic development, as well as improved quality of life for citizens (Fernandez-Anez et al. 2018; Hashem et al. 2016). The latter is an inevitable source for entrepreneurship, which in its turn generates new knowledge necessary for smart city development (Scornavacca et al. 2020).

Entrepreneurship as a phenomenon is researched from various perspectives, including its nature and developmental paths in the urban environment (Audretsch et al. 2019; 
Glaeser 2007; Glaeser et al. 2010; Pacut 2020). One of the key issues discussed by scholars is the spatial determinants of entrepreneurship, or, in other words, identification of local conditions that encourage entrepreneurship (Fritsch and Falck 2007; Audretsch et al. 2012; Ghani et al. 2014). Each location is characterized by the unique combination of knowledge and cultural traits which determine the availability and content of the profit opportunities that can be discovered by entrepreneurs (Andersson 2005). Empirical evidence based on the analyses of 21 economies within a period of 7 years shows that entrepreneurial policies need to be adjusted to specific locations in order to influence the growth of entrepreneurial action (Pita et al. 2021). With the growing attention of researchers to smart cities, much of the academic literature discusses the role entrepreneurship plays in developing smart cities (Richter et al. 2015a; Kummitha 2019; Schiavone et al. 2020). However, there is a lack of emphasis in the literature on digital entrepreneurship (DE) in the context of smart cities (Kraus et al. 2018; Manjon et al. 2019).

Moreover, nowadays, the concept of digital entrepreneurship is considered as part of the digital entrepreneurial ecosystem (DEE) that provides the environment for effective entrepreneurial activities (Spigel 2015; Li et al. 2017; Sussan and Acs 2017; Elia et al. 2020). The term "ecosystem" was transferred from natural science to economics and business administration research to explain the complexity of the interactions between individuals and organizational stakeholders. Just as the natural ecosystems generate benefits known as ecosystem services, the entrepreneurial ecosystem creates resource allocation aimed at productive usage, innovation, and high-growth ventures (Autio and Levie 2017).

In such a context, the main goal of this research-revealing the interconnection between DEE and smart cities and the contribution of this relationship to their mutual development-is both urgent and necessary. In order to achieve this goal, the present work seeks to address the following research questions:

RQ1: What is the interplay between DEE and smart cities?

RQ2: Do they actually affect each other development?

RQ3: What is the contribution of DEE to the smart city dimensions?

In order to answer such research questions, this paper is organized as follows: firstly, we provide a literature review on issues of smart cities, digital entrepreneurship, and digital entrepreneurial ecosystem to accurately identify the gap present in the literature. Then, we describe the methods used to reveal the interconnection between the digital entrepreneurial ecosystem and smart city development. We consider each component of DEE and its interconnection with smart cities to establish its role in SC development. As the main result of the research, we reveal the contribution of DEE for each dimension of smart city development and present the model of DEE engagement in smart city architecture.

\section{Literature Review}

\subsection{Smart Cities and Entrepreneurship}

Despite the ongoing initiatives at the governmental level to develop smart cities and sustainable urban environments, there is no universal comprehensive definition of smart cities accepted both in the scientific literature and at the institutional level (Gil-Garcia et al. 2015; Yigitcanlar et al. 2019). This term is widely used in different research fields and takes on different meanings depending on the context. On the one hand, some researchers stress the importance of the infrastructure in smart cities and their ability to provide effective and affordable transportation systems, power and water supply, and ICTs (Harrison et al. 2010; Toppeta 2010; Silva et al. 2018; Salkuti 2021; Abu-Rayash and Dincer 2021). On the other hand, other researchers consider the smart city as a set of factors that affect and raise the innovative and entrepreneurial potential of the city, allow attracting human capital and develop cultural and creative activities. Their vision leans toward the inclusiveness of the citizens and communities' engagement in the city's everyday life (Kourtit et al. 2012; Kummitha 2018; Mittal and Sethi 2018; Laitinen and Piazza 2020). The variety of definitions justifies that the term "smart city" identifies cities through a wide range of attributes to favor efficient and sustainable incentives for economic development 
and entrepreneurial growth to provide high-quality life and inclusiveness for the citizens. This means that one of the main characteristics of a smart city resides in its ability to generate entrepreneurial activities to attract investments and create a competitive business environment in the city context (Komninos and Mora 2018; Antonov et al. 2021).

The abundance of smart city definitions stimulates the discussion on its dimensions. The scientific literature is rich in studies on this topic and helps to define them from different perspectives. These dimensions define basic requirements and enable conditions and core components for the comprehensive conceptualization of the smart city phenomenon. Giffinger and Gudrun (2010) have developed six characteristics that determine the city as smart. One of them is "economy", in terms of competitiveness, which therefore involves innovative spirit in the city and development of local entrepreneurship enhanced by the environment to dynamically transform and meet changes. Another group of scholars, Nam and Pardo (2011), after a thorough study of the scientific literature, has defined a smart city as an interconnection of three main dimensions, made of technological, institutional, and human factors. The category of human factors is represented by learning, creativity, and knowledge transfer that make a smart city attractive for creative human capital. The model elaborated by Chourabi et al. (2012) has stipulated eight factors that define a smart city and establish a basis for an integrative framework. In this model, the elements characterizing entrepreneurship in the cities are distributed among different factors of the model and reflect the challenges that smart cities face as well as the strategies to overcome them-business process improvement, adequate training and funding, integration of skills and culture among the employees, etc. The model of Gil-Garcia et al. (2015) consists of four main elements - technology and data, physical environment, society, and government. The society element includes the development of knowledge economy, encouraging creativity, engagement and collaboration.

The smart city definition also includes the role of talent discovery and entrepreneurship. Scholars often address the question of whether entrepreneurship is promoted in smart cities through the creation of new enterprises or ICT companies that form the entrepreneurial core in the smart city, play a key role in other entrepreneurial endeavors, and drive entrepreneurship. The findings of the study conducted by Barba-Sánchez et al. (2019) show that the smartness level of a city affects the entrepreneurial activities and technological level. Furthermore, the technological level that distinguishes the smart city from other locations is an intermediary for the relationship between the entrepreneurial activity of the city and its smartness level. Kummitha (2018) analyses the concerns characterizing the entrepreneurial-driven smart city model, summarized in four main areas: the usage, appropriation, and effectiveness of technology; social polarization; switching costs; and data management. By building upon these concerns, the paper offers a number of suggestions for policymakers to take effective steps toward inclusive planning. The author suggests potential policymakers invest in knowledge-based urban development programs to enable community knowledge and skills. Beyond this, policymakers are encouraged to shift their smart city projects from a technology city to a social city where technology is developed and used by human agents instead of promoting the technologies above human propensity. More recently, Trencher (2019), by exceeding the heavily critiqued first-generation smart city 1.0 paradigm, examined the theoretical characteristics of the second generation (the so-called smart city 2.0), conceptualized as a "decentralized, people-centric approach where smart technologies are employed as tools to tackle social problems, address resident needs and foster collaborative participation". Furthermore, Yun and Lee (2019) proposed a Smart City 4.0 model where the city is the main agent of production supported by enhanced connectivity and entrepreneurship. All the models discussed above have similar attributes and prove the importance of entrepreneurship development in smart cities.

The smart city dimensions defined and discussed in the literature, together with the contents concerning the concept of DE discussed in the next section, are fundamental building blocks to create our comprehensive framework and the internal/external relationships which regulate its functioning. 


\subsection{Digital Entrepreneurship and Digital Entrepreneurial Ecosystem}

The scope and boundaries of DE are uncertain, and substantial literature reviews across this domain (Kraus et al. 2018; Zaheer et al. 2019) help to understand the complexity of the phenomenon, including differences from traditional entrepreneurship, and possible implications for various fields of research beyond management and business. It is worth noting that $\mathrm{DE}$ is not based on single new developments in the field, but rather on opportunities that emerged due to digitalization for new venture creation and for already existing enterprises to alter from offline to an online presence (Kraus et al. 2018). Sahut et al. (2019) suggest that research on digital entrepreneurship can be categorized into two main groups: studying how technologies transform entrepreneurship, and exploring the generation of entrepreneurial opportunities with the help of digital technologies. In the first category, digital technologies serve as enablers, while in the second, these technologies perform both as enablers and outputs.

A few definitions of DE can exemplify the fragmented nature of the existing research. Hull et al. (2007) define DE as "a subcategory of entrepreneurship in which some or all of what would be physical in a traditional organization has been digitized". Davidson and Vaast (2010) refer to DE as pursuing "new venture opportunities presented by new media and internet technologies". When digital entrepreneurs rely upon the features of digital media and IT, "they exacerbate changes in the competitive landscape, as they attempt to seize the opportunities". Three interrelated types of opportunities are presented in the study: business, knowledge, and institutional. Hair et al. (2012) state that in $\mathrm{DE}$ "some or all of the entrepreneurial venture takes place digitally" and identify that products, distribution, the workplace, and other things can take digital forms in a new venture. Giones and Brem (2017) propose to discuss the DE through a revision of the term "technology entrepreneurship" and conceptualize three different phenomena: technology entrepreneurship, digital technology entrepreneurship, and digital entrepreneurship. They put the following technologies behind the opportunity: "new products and services based on the internet. Services running only in the cloud; using big data or artificial intelligence" (p. 45). Le Dinh et al. (2018) also mention the internet and ICTs as the technological assets through which DE emerged.

In this context, the variety of definitions can be explained by the development and practical use of ICTs. Zaheer et al. (2019) highlight three phases of it. The first phase is characterized by a modest number of internet users, and the role of the internet in creating enterprise value, which was predominantly functional. The rise of portals, directories and search engines falls in this phase. The second phase is featured as 'e-entrepreneurship' and, together with the content, the process in entrepreneurial activities is digitized. Broadband networks, mobile devices, and the rise of social media create user-generated content and change our perception of interaction. The third phase, according to the authors, is actual digital entrepreneurship. There is an "environment of ubiquitous connectivity", where business model transformation takes place. Individuals are no longer in the focus as the shift is made towards "digital entrepreneurial ecosystems which encourage shared and distributed entrepreneurial agencies, processes, and outcomes". By consolidating the literature about digital ecosystems and entrepreneurial ecosystems, the concept of the "Digital Entrepreneurial Ecosystem" (DEE) appears as a new framework for understanding the role of entrepreneurship and digital entrepreneurship in the digital era (Purbasari et al. 2021). Some authors consider Digital Entrepreneurship Ecosystems as "an ecosystem where digital entrepreneurship emerges and develops" (Li et al. 2017), and it is suggested that it is crucial for digital entrepreneurship development because it can integrate resources and facilities beyond the firm level (Spigel 2015). Sussan and Acs (2017) suggest a DEE framework as the interconnection of four key concepts: digital infrastructure governance, digital user citizenship, digital entrepreneurship, and digital marketplace.

At the same time, Song (2019) suggests several improvements to the "Digital Entrepreneurial Ecosystem" framework. The author reintroduces the Digital User Citizenship concept more broadly and includes users on the demand side and the supply side and 
replaces the Digital Entrepreneurship concept by Digital Technology Entrepreneurship, a broader concept including app developers and all other agents producing goods and services that connect to the platform; in addition, the author replaces Digital Marketplace with the concept of Digital Multi-sided Platforms. These improvements were made to provide a sustainable version of DEE. According to this research, a sustainable DEE is "one in which user privacy is protected, platform efficiency enhanced by third-party agents, market competition is not stifled by platforms, and security of digital infrastructure ensured" (Song 2019).

Some cities (ex. London, Paris, Berlin, Tel Aviv, Singapore, etc.) used DEE development for revival economies and provided acceleration of start-ups (especially digital innovation projects). There are many actors involved in DEE, and they have different goals (Li et al. 2017). The main question is how to achieve them all. Each participant may prefer to act to its benefit and create value only for itself rather than consider the interests of other participants. This may lead to conflicts and obstacles in DEE development.

Nevertheless, there is an opinion that little discussion on the DEE is present in the literature, so that there are still limitations to the resulting DEE framework (Song 2019; Purbasari et al. 2021). At the same time, to the best of our knowledge, no exiting study highlights DE and DEE as a fundamental dimension or as the enabler of smart cities. All the studies published in this research field emphasize the importance of entrepreneurship for smart city and its necessity as the main factor for smart city functioning. However, there are no studies devoted to revealing the role of DEE in smart city development. So, our study aims to fill this research gap and contribute to smart city and DEE literature by revealing the interconnection of DEE with smart cities and their possible contribution to their joint development.

\section{Methodology}

The nature of this study is exploratory. It aims to analyze and understand the bilateral relationship between DEE and SC dimensions by providing reliable definitions of the elements involved in this complex system through the study of theories and models retrieved from rigorous sources. For this reason, the initial objective of the authors-which is reflected in the research questions-was to offer a clear overview of the main components taken into consideration as well as their interconnections.

To do so, as a first step of the research, a thorough literature review on the topic was conducted. The literature review aims to examine the current state of the art of the literature on smart cities, their dimensions, smart city model evolvement, and the role of entrepreneurship in it. Following that, the concept of DE and the shift towards DEE were studied. The evidence from the literature, integrated with information derived from official documents and recent reports of the EU, were used to design and characterize the constituents of the final framework presented in section four. This approach allowed the authors to reveal also the existing literature gap on the role of DEE in smart city development.

To explore the importance of DEE for smart cities, the DEE model elaborated by the Global Entrepreneurship and Development Institute was used; the authors carefully considered each component of the DEE model and its' interconnection with smart cities in order to answer the research questions RQ1 and RQ2 defined in the introduction section. At the same time, the SC model was derived from the European Parliament SC report (Manville et al. 2014). It presents six fundamental axes or dimensions: Smart Economy, Smart Mobility, Smart Environment, Smart People, Smart Living, and Smart Governance. To answer the RQ3 and qualify the connection between smart cities dimensions and the contribution of DEE to each one of its elements, in addition to the aforementioned model, the authors used an updated version proposed by Van der Hoogen et al. (2019) as a reference. 


\section{Results and Discussion}

As mentioned, one of the main characteristics of the smart city model is its ability to generate entrepreneurial activities. Another one is its digitalization-smart telecommunication networks, intelligent transportation systems, and developed energy infrastructure are some examples of this area (Amović et al. 2021). The ongoing technological development together with the emergence of DEE and the appearance of smart cities give the unique possibility for rising effectiveness of capital usage- by making decisions based on actual data. It is known that today, data is the new gold and smart cities have a great capacity to provide a high-quality hard infrastructure as well as availability to collect, analyze and provide useful information (Richter et al. 2015b). For instance, if someone wants to perform marketing research before opening a new restaurant, there is no need to visit the place and count people passing by its potential location. It is possible to obtain data from city cameras located close to the place and use one of the hundreds of big data analysis algorithms to estimate relevant people flows.

The shopping mall business development is an example. Today, every smartphone (and mobile provider) collects large amounts of data about its owner. When a person enters a shopping mall, the mobile provider gives impersonalized information to the mall data center (like gender, age, etc.). So, mall owners can provide their tenants with reliable information about the target audience (Lee et al. 2013).

Therefore, smart city infrastructures provide great opportunities for data collecting, and this allows DEE to be implemented. It would be difficult to imagine a DEE without the possibility to make data-driven decisions.

In this study, we consider DEE as the interconnection of four key concepts: digital user citizenship, digital infrastructure governance, digital entrepreneurship, and digital marketplace (Sussan and Acs 2017). For answering our research questions, we consider each component of DEE and its interconnection with smart cities as reported below in Table 1.

Table 1. Digital entrepreneurial ecosystem for smart cities.

\begin{tabular}{|c|c|c|c|}
\hline \multirow{6}{*}{ 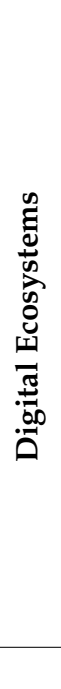 } & & Digital user citizenship & Digital marketplace \\
\hline & $\begin{array}{l}\stackrel{\infty}{\sharp} \\
\stackrel{\omega}{\omega}\end{array}$ & $\begin{array}{l}\text { A smart city has the necessary capacity to collect a large amount of } \\
\text { data and to provide it to those who need it and can use it. At the } \\
\text { same time, SC should provide user privacy since public trust is a } \\
\text { prerequisite to user participation in the digital economy (The } \\
\text { Global Entrepreneurship and Development Institute 2020). }\end{array}$ & $\begin{array}{l}\text { A smart city provides a great opportunity for } \\
\text { cooperation and interaction between agents } \\
\text { and users, which in turn creates digital } \\
\text { platforms and stimulates market competition, } \\
\text { innovation, and entrepreneurial activities. }\end{array}$ \\
\hline & \multirow{3}{*}{ 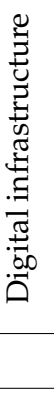 } & Digital infrastructure governance & Digital entrepreneurship \\
\hline & & $\begin{array}{l}\text { Provide both technological and legal basis for the use of data } \\
\text { collected by a smart city and is responsible for keeping the digital } \\
\text { economy open and secure. } \\
\text { Governments of SC have to enact and enforce rules and regulations, } \\
\text { which protect the data-usage process and provide security of } \\
\text { digital infrastructure, maximizing the economic and social effects } \\
\text { deriving from a smart city infrastructure usage. }\end{array}$ & $\begin{array}{l}\text { A smart city attracts cultural and creative } \\
\text { human capital that, in turn, raises the } \\
\text { entrepreneurial innovation capacity of the } \\
\text { city and its investment attractiveness, thereby } \\
\text { increasing its digital marketplace efficiency. }\end{array}$ \\
\hline & & Institutions & Agents \\
\hline & & Entrepreneurial Ecosystems & \\
\hline
\end{tabular}

Digital user citizenship is a prerequisite for the appearance of both smart cities and DEE. Neither traditional nor digital economy can exist without people who contribute to its development by taking part in different transactions. This collaborative consumption and bottom-up involvement are typical of the collaborative economy (CE) paradigm (Ertz and Boily 2019). The commonly accepted digital user citizenship concept undermines that citizens are ready to agree on a new kind of social contract by providing their data to the state or third parties such as commercial or financial organizations. This is a sharp issue 
due to both legal and ethical aspects, which can differ significantly from state to state and from one culture to another. It is realistic to expect that soon, new international institutes will try to elaborate international standards for this issue. Digital user citizenship makes it possible to collect an even larger amount of data. A smart city has the necessary capacity to collect those data and to provide them to those who need it to enhance the number and quality of services for the citizens. DEE can use this data to help people make datadriven decisions, which helps to increase business effectiveness and cut unnecessary costs. Moreover, it allows driving more efficient decision-making and business processes-for instance, testing different business opportunities, as was considered in our example with a new restaurant.

Digital infrastructure governance can provide both a technological and legal basis for the use of data collected in/by a smart city. Nowadays, the digital government environment has developed rapidly (Baheer et al. 2020). The creation of any kind of infrastructure implies a significant amount of investment that is hard to achieve without the authority's assistance. Funds can be provided by state or by private investors, but under state guarantees. When technical infrastructure is ready, the authority elaborates rules under which it will work, and different actors can gain access to it. So, there shall be common rules that can guarantee nondiscrimination and maximum economic and social effect of smart city infrastructure usage.

Digital marketplace in a smart city provides great possibilities for cooperation and interaction between agents and users in a community scenario. According to Sussan and Acs (2017), a "digital marketplace that relies more on value co-creation between users and agents will be more beneficial to a sustainable digital entrepreneurial ecosystem". This interaction helps to improve different products in ways that users need. For instance, if the user is not satisfied with goods or service, he/she can post a comment with a description of the problem. This comment allows the agent to understand what the problem is and make necessary changes. Moreover, the product/service provider can react to the comment to avoid losing a client. Even if users do not leave any comments, the smart city infrastructure allows understanding of what is wrong with products or business processes. For instance, a company can track a digital pathway of the user and understand exactly at which step he/she makes the decision not to buy. A smart city also provides access to different data so that actors can not only improve existing products, but also find estimate segments with unsatisfied demands, creating new products aimed at these segments.

Digital entrepreneurship makes economical use of the three above-mentioned blocks. It uses technological infrastructure to produce and deliver new products to users through digital marketplaces. Different variants of businesses can appear, and there is no need to list them. The main achievement is that digital entrepreneurship can bring more wealth to all stakeholders (governments, firms, entrepreneurs, customers/users) when there is an ecosystem that provides the possibility to build the business upon data-driven decisions (Borghys et al. 2020).

It is noteworthy that being a smart city is an ongoing process: it is necessary to make alterations and contribute to technological infrastructure innovation as technologies depreciate very fast. In smart cities, digital entrepreneurship also acts as an agent of change, which helps authorities to understand how to anticipate or address the change and not to lose competitive advantages provided by being a modern smart city.

Based on our analysis in Table 2, we track the connection between SC dimensions and structural constituents of DEE, highlighting the contribution of each element and identifying antecedents and consequences of the underlying relationships. We adopt the smart city model of Van der Hoogen et al. (2019) but integrate it by interpreting several other studies (indicated as references in the table) to explore the complexity of its fundamental dimensions.

As it derives from Table 2, there is an ongoing debate on the definition and role of smart city dimensions. Moreover, there is a lack of discourse on DEE's contribution to the development of smart cities. Hence, nine smart city dimensions were analyzed from the 
perspective of how DEE contributes to their development as well as helps them flourish by providing innovative solutions, bringing stakeholders, and ensuring constant inflows of ideas, people and technologies. DEE provides ground for the creation of business models that can be tested both locally and internationally, helping a smart city to become an attraction point of high potential people with demanded skills and knowledge. It also allows smart technologies and infrastructure to profitably protect the environment and contribute to the development of sharing and platform economies, to provide transport efficiency, and enable new approaches to urban smart mobility. DEE needs e-government to provide transparency and efficiency of the decision-making process and facilitate innovative bottom-up and inclusive solutions in the city.

Table 2. Contribution of DEE for smart city dimensions development.

\section{SC Dimensions SC Dimension in the Literature}

Smart economy is identified in terms of urban economic growth and together with the development of ICT technologies (Anthopoulos 2017).

Smart economy is one of the key strategic action fields

Smart economy for smart city development and describes it as a set of measures to transform and strengthen the urban economy (Smart City Indicators 2019).

The smart economy concept is based on three pillars: enterprise and innovation, productivity and local and interconnectedness (Yudono et al. 2019).

Smart cities need a flexible, up-to-date ICT platform that becomes real technical support for smart cities'

Smart technology development (Chichernea 2015).

and ICT The main indicators of the smart ICT system in the infrastructure urban environment are mobile communication environment, urban hardware facilities and logistics system. (Cai et al. 2020)

Smart environment is a knowledge-based system aimed at building a sustainable and harmonious environment. Ecological issues and biodiversity play a vital role in citizens' welfare and can be reached by means of

Smart environment implementation of smart resource management and using ICT and IoT technologies (Vinod 2020).

The role of technology is important for the efficient use of resources, improving knowledge about environmental services, and changing people's habits (Aletà et al. 2017)

Smart mobility is based on applying innovative technical solutions and different alternative mobility services (Schulz et al. 2021).

A reduced ecological footprint due to traffic congestion decrease and route optimization is one of the essential

Smart mobility factors of smart mobility together with the promotion of active and inclusive mobility, encouraging the use of environmentally friendly vehicles and citizens' engagement (Paiva et al. 2021).

The smart mobility concept includes improving public transport services, real-time traffic monitoring and management (Prakash 2021).

\section{Contribution of DEE to the Smart} City Dimensions

Creation of new business opportunities that can significantly affect the economy of a smart city. DEE allows creating of business models that can be tested on the local site and then be scaled to the international level.

Moreover, well-developed DEE can help a smart city to become an attraction point for high-potential people with in-demand skills and knowledge. The concentration of such people in a smart city territory can form an IT cluster that will attract more and more people and financial resources to the smart city.

DEE helps to make smart technologies and infrastructure profitable. Collecting data and the creation of technological infrastructures requires significant investments. DEE helps to find clients who are ready to pay for collected data or infrastructure usage. Thus, investments become reasonable and accumulate free cash flow, which is necessary for further technological development.

DEE contributes to protecting the environment by reducing the burden on the use of natural resources. The clearest example of DEE contribution in this area are sharing and platform economies, which are closely connected with digital entrepreneurship and create opportunities both for entrepreneurs and consumers.

To provide transport efficiency, smart cities must constantly analyze information on citizens' mobility demand and the state of public transport. Smart cities need to collect statistical data on the behavioral patterns of their citizens. DEE enables new approaches to urban smart mobility by providing tools and infrastructure for this process. 
Table 2. Cont.

\begin{tabular}{lll}
\hline SC Dimensions & SC Dimension in the Literature & $\begin{array}{l}\text { Contribution of DEE to the Smart } \\
\text { City Dimensions }\end{array}$ \\
\hline & $\begin{array}{l}\text { The smart people dimension of SC refers to the social } \\
\text { and human capital in terms of qualification, lifelong } \\
\text { learning, inclusiveness, creativity, and participation } \\
\text { level in public life (Giffinger and Gudrun 2010). } \\
\text { No significant further development of this topic was } \\
\text { carried out onwards (Ninčević et al. 2021). }\end{array}$ & $\begin{array}{l}\text { DEE requires talented and well-educated people } \\
\text { and, at the same time, creates the conditions for } \\
\text { the appearance of such people. }\end{array}$ \\
& $\begin{array}{l}\text { Knowledge dissemination happens faster in these } \\
\text { conditions. Moreover, it is common practice when } \\
\text { big companies run their educational programs to } \\
\text { prepare and hire people to satisfy their demand for } \\
\text { human capital with relevant skills. }\end{array}$
\end{tabular}

Three main components of the smart governance dimension are societal goals, collaboration and technologies (Tomor et al. 2021).

The role of technologies is important to achieve
governance and better outcomes for the urban governance environment (Jiang 2021).

The main goal of smart governance is to achieve sustainable urban development and improved coordination of the stakeholders in the process (Nguyen and Dao 2020).

Smart living is based on three main pillars: energy, mobility and waste. These categories are applicable on both local and global levels in rural and urban

Smart living environments (Zavratnik et al. 2020).

Being an equivalent of smart cities, the smart living dimension includes other components, such as smart people, smart mobility, smart economy, smart environment and smart government (Vinod 2020).

Smart organizations should support more flexible processes and collaboration between the stakeholders

Smart organisation and adapt their knowledge management systems to promote more collaborative and innovative communities in their ecosystems, encouraging a more transparent and inclusive environment (Lima 2020).

The city administration's policy directions are directly connected to the strategies aimed at making the city Smart policy smarter. In some cases, direct support of the mayor significantly affects the implementation of smart initiatives in the city (Alawadhi et al. 2012).
DEE needs e-government to provide transparency and efficiency of the decision-making process. At the same time, it helps to ensure the transition of local governments from being bureaucratic barriers to become facilitators of innovative bottom-up and inclusive solutions.

DEE provides great opportunities for smart living by providing comfortable infrastructure for the citizens.

Digital technologies make everyday life easier with solutions for various domains of urban life based on technology, connectivity, and data analytics (Gassmann et al. 2019) and creating new business model possibilities.

In e-business, there are many remote vacancies, and after COVID-19 lockdowns, the number of such vacancies has increased. This allows joining talented people from all over the world without forcing them to physically move to one place.

The stakeholders of DEE become inevitable actors of the smart city policy development and implementation, making their impact on the development strategies of the city.

The above-mentioned approach allowed us to design the model of DEE engagement in smart city architecture (see Figure 1).

This framework represents the bilateral interaction between a smart city and DEE and its components through the analysis of nine smart city dimensions, defining DEE as an inevitable part of the smart city environment. 


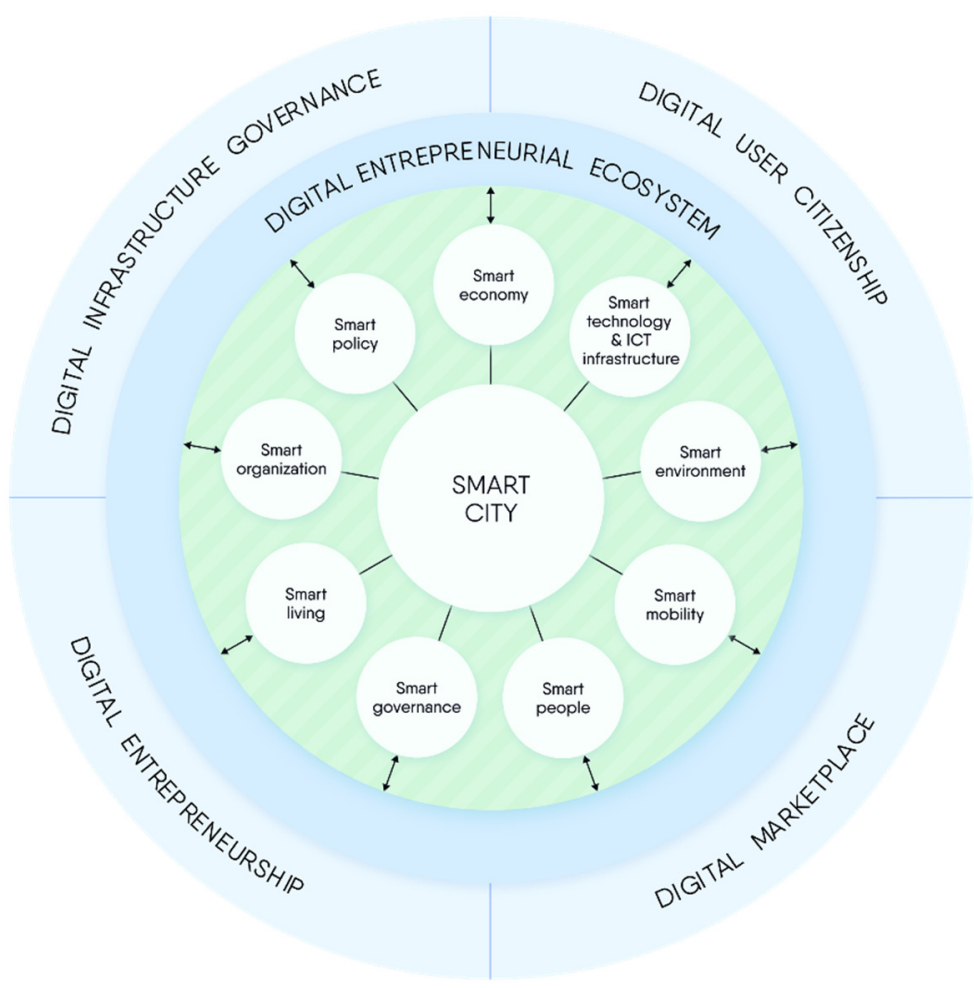

Figure 1. The model of digital entrepreneurial ecosystem engagement in smart city architecture (own elaboration).

\section{Conclusions}

Entrepreneurship occupies one of the central places in the development of regions and cities. The proliferation of smart cities is pushing governments to focus their efforts on increasing public value creation. The SC objectives and management exceed traditional institutions' resources, capabilities, and scope, as well as their classic processes of governing. Consequently, new and innovative forms of governance are needed. Indeed, the creation of public value in the context of smart cities resides on high levels of urban collaboration among different stakeholders, which promotes the use of new technologies to adopt a more participative model of governance (Rodríguez Bolívar 2018).

Digital technologies have developed significantly in recent years, becoming an integral part of various spheres of the urban environment and contributing to the development of smart cities. These technologies boost the development of digital entrepreneurship, which is one of the building blocks of DEE.

In this paper, the interconnection between smart cities and DEE and its contribution to their mutual development were studied. A strong interconnection was established due to the contribution of each of DEE components-digital user citizenship, digital infrastructure governance, digital entrepreneurship, and a digital marketplace-into smart city development. At the same time, it was established that smart cities create prerequisites for effective DEE development by providing the necessary infrastructure.

The evidence of this paper showed that DEE contributes to each of the nine smart city dimensions, positively affecting their development and growth.

The main outcome of the research consists of designing the model of DEE engagement in smart city infrastructure. This framework shows the bilateral nature of the interaction process between DEE and smart city.

This study has some limitations that mainly lie in its exploratory nature. In order to obtain a comprehensive analysis of the role of DEE for smart city development, the engagement of different stakeholders in the research is needed. Thus, future studies will be aimed at the conduction of round tables and interviews with smart city stakeholders 
and practitioners that will provide the academic community with sufficient evidence on the role of DEE in smart city development from the practical side.

Despite the above-mentioned limitations, our research presents some interesting theoretical, empirical, and policy implications. So, the theoretical contribution of the present study consists of the expansion of the role of digital entrepreneurship in the smart city environment, which was previously neglected in the literature. Entrepreneurship in the smart city is a robust building block that can be considered as a smart city dimension in future scientific studies. In addition, the evidence obtained from an extensive literature review of sources published in different domains (i.e., academic, institutional, managerial) allowed us to introduce a new conceptual framework that includes both SC and DEE and their dimensions and interplay.

The managerial implication of this paper resides in the evidence that smart city stakeholders can consider digital entrepreneurship and DEE of the city as a driver for smart city development, which has a significant potential to leverage various spheres of urban life. From an institutional and political viewpoint, the present results can support governments and local administration in improving their role in the urban innovation ecosystem, through research and innovation projects and programs, with the goal of increasing the effectiveness and efficiency of public service delivery. These outcomes also have a strong social and economic impact on urban development; hence, the development of entrepreneurial activities in the city prompts advancements in other spheres of urban life.

Author Contributions: Conceptualization, I.G., D.D., M.D. and M.S.; methodology, I.G., D.D., M.D. and M.S.; writing—original draft preparation, I.G., D.D., and M.D.; writing—review and editing, M.S., I.G., D.D. and M.D.; visualization, I.G.; supervision, M.S.; project administration, I.G. All authors have read and agreed to the published version of the manuscript.

Funding: This research received no external funding.

Institutional Review Board Statement: Not applicable.

Informed Consent Statement: Not applicable.

Conflicts of Interest: The authors declare no conflict of interest.

\section{References}

Abu-Rayash, Azzam, and Ibrahim Dincer. 2021. Development of integrated sustainability performance indicators for better management of smart cities. Sustainable Cities and Society 67: 102704. [CrossRef]

Alawadhi, Suha, Armando Aldama-Nalda, Hafedh Chourabi, J. Ramon Gil-Garcia, Sofia Leung, Sehl Mellouli, Taewoo Nam, Theresa A. Pardo, Hans J. Scholl, and Shawn Walker. 2012. Building Understanding of Smart City Initiatives. In Electronic Government. Edited by Hans Jochen Scholl, Marijn Janssen, Maria Wimmer, Carl Erik Moe and Leif Skiftenes Flak. EGOV 2012. Lecture Notes in Computer Science. Berlin/Heidelberg: Springer, vol. 7443.

Aletà, Neus, Baucells Alonso, Concepción Moreno, and Ruiz Rosa M. Arce. 2017. Smart mobility and smart environment in the Spanish cities. Transportation Research Procedia 24: 163-70. [CrossRef]

Amović, Mladen, Govedarica Miro, Radulović Aleksandra, and Janković Ivana. 2021. Big Data in Smart City: Management Challenges. Applied Sciences 11: 4557. [CrossRef]

Andersson, David Emanuel. 2005. The spatial nature of entrepreneurship. The Quarterly Journal of Austrian Economics 8: 21-34. [CrossRef]

Anthopoulos, Leonidas G. 2017. Understanding Smart Cities: A Tool for Smart Government or an Industrial Trick? Berlin: Springer International Publishing.

Antonov, Viktor, Petrenko Elena, and Kuptsova Ekaterina. 2021. The Development of Smart Entrepreneurship as a Driver of the Smart Economy. Lecture Notes in Networks and Systems 155: 1754-60.

Audretsch, David B., Belitski Maksim, and Desai Sameeksha. 2019. National business regulations and city entrepreneurship in Europe: A multilevel nested analysis. Entrepreneurship Theory and Practice 43: 1148-65. [CrossRef]

Audretsch, David B., Oliver Falck, Maryann P. Feldman, and Stephan Heblich. 2012. Local entrepreneurship in context. Regional Studies 46: 379-89. [CrossRef]

Autio, Erkko, and Jonathan Levie. 2017. Management of Entrepreneurial Ecosystems. In The Wiley Handbook of Entrepreneurship. Edited by Gorkan Ahmetoglu, Tomas Chamorro-Premuzic, Bailey Klinger and Tessa Karcisky. Chichester: John Wiley \& Sons, pp. 423-49. 
Baheer, Baseer Ahmad, David Lamas, and Sonia C. Sousa. 2020. A Systematic Literature Review on Existing Digital Government Architectures: State-of-the-Art, Challenges, and Prospects. Administrative Sciences 10: 25. [CrossRef]

Barba-Sánchez, Virginia, Arias-Antúnez Enrique, and Orozco-Barbosa Luis. 2019. Smart cities as a source for entrepreneurial opportunities: Evidence for Spain. Technological Forecasting and Social Change 148: 119713. [CrossRef]

Borghys, Koen, Shenja Van Der Graaf, Nils Walravens, and Mathias Van Compernolle. 2020. Multi-Stakeholder Innovation in Smart City Discourse: Quadruple Helix Thinking in the Age of "Platforms". Frontiers in Sustainable Cities 2: 5. [CrossRef]

Cai, Zipan, Cvetkovic Vladimir, and Page Jessica. 2020. How does ICT expansion drive "smart" urban growth? A case study of Nanjing, China. Urban Planning and the Smart City: Projects, Practices and Politics 5: 1. [CrossRef]

Chichernea, Virgil. 2015. Smart cities communities and Smart ICT platform. Journal of Information Systems E Operations Management 9: $1-11$.

Chourabi, Hafedh, Nam Taewoo, Walker Shawn, Gil-Garcia J. Ramon, Mellouli Sehl, Nahon Karine, Theresa A. Pardo, and Scholl Hans Jochen. 2012. Understanding Smart Cities: An Integrative Framework. Paper presented at 45th Hawaii International Conference on System Sciences, Maui, HI, USA., January 4-7.

Davidson, Elizabeth, and Emmanuelle Vaast. 2010. Digital Entrepreneurship and Its Sociomaterial Enactment. Paper presented at the 43rd Hawaii International Conference on System Sciences, Kauai, HI, USA, January 5-8; pp. 1-10.

Elia, Gianluca, Alessandro Margherita, and Giuseppina Passiante. 2020. Digital entrepreneurship ecosystem: How digital technologies and collective intelligence are reshaping the entrepreneurial process. Technological Forecasting and Social Change 150: 119791. [CrossRef]

Ertz, Myriam, and Émilie Boily. 2019. The rise of the digital economy: Thoughts on blockchain technology and cryptocurrencies for the collaborative economy. International Journal of Innovation Studies 3: 84-93. [CrossRef]

Fernandez-Anez, Victoria, José Miguel Fernández-Güell, and Rudolf Giffinger. 2018. Smart City implementation and discourses: An integrated conceptual model. The case of Vienna. Cities 78: 4-16. [CrossRef]

Fritsch, Michael, and Oliver Falck. 2007. New industry formation by industry over space and time: A multidimensional analysis. Regional Studies 41: 157-72. [CrossRef]

Gassmann, Oliver, Böhm Jonas, and Palmié Maximilian. 2019. Smart Cities: Introducing Digital Innovation to Cities. Bingley: Emerald Group Publishing.

Ghani, Ejaz, William Kerr, and Stephen O'connell. 2014. Spatial determinants of entrepreneurship in India. Regional Studies 48: 1071-89. [CrossRef]

Giffinger, Rudolf, and Haindlmaier Gudrun. 2010. Smart cities ranking: An effective instrument for the positioning of cities? ACE: Architecture, City \& Environ 4: 7-25.

Gil-Garcia, J. Ramon, Theresa A. Pardo, and Taewoo Nam. 2015. What makes a city smart? Identifying core components and proposing an integrative and comprehensive conceptualization. Information Polity 20: 61-87. [CrossRef]

Giones, Ferran, and Alexander Brem. 2017. Digital technology entrepreneurship: A definition and research agenda. Technology Innovation Management Review 7: 44-51. [CrossRef]

Glaeser, Edward L. 2007. Entrepreneurship and the City (No. w13551). Working Paper. Cambridge: National Bureau of Economic Research.

Glaeser, Edward L., Stuart S. Rosenthal, and William C. Strange. 2010. Urban economics and entrepreneurship. Journal of Urban Economics 67: 1-14. [CrossRef]

Hair, Neil, Wetsch Lyle, Hull Clyde Eiríkur, Perotti Victor, and Hung Yu-Ting Caisy. 2012. Market orientation in digital entrepreneurship: Advantages and challenges in a Web 2.0 networked world. International Journal of Innovation and Technology Management 9: 1250045. [CrossRef]

Harrison, Colin, Barbara Eckman, Rick Hamilton, Perry Hartswick, Jayant Kalagnanam, Jurij Paraszczak, and Peter Williams. 2010. Foundations for smarter cities. IBM Journal of Research and Development 54: 350-65. [CrossRef]

Hashem, Ibrahim Abaker Targio, Victor Chang, Nor Badrul Anuar, Kayode Adewole, Ibrar Yaqoob, Abdullah Gani, Ejaz Ahmed, and Haruna Chiroma Chang. 2016. The role of big data in smart city. International Journal of Information Management 36: 748-58. [CrossRef]

Hull, Clyde Eiríkur, Yu-Ting Caisy Hung, Neil Hair, Victor Perotti, and Richard DeMartino. 2007. Taking advantage of digital opportunities: A typology of digital entrepreneurship. International Journal of Networking and Virtual Organizations 4: 290-303. [CrossRef]

Jiang, Huaxiong. 2021. Smart urban governance in the 'smart' era: Why is it urgently needed? Cities 111: 103004. [CrossRef]

Komninos, Nicos, and Luca Mora. 2018. Exploring the big picture of smart city research. Scienze Regionali 17: 15-38.

Kourtit, Karima, Nijkamp Peter, and Arribas Daniel. 2012. Smart cities in perspective-A comparative European study by means of self-organizing maps. Innovation: The European Journal of Social Science Research 25: 229-46. [CrossRef]

Kraus, Sascha, Palmer Carolin, Kailer Norbert, Kallinger Friedrich Lukas, and Spitzer Jonathan. 2018. Digital entrepreneurship: A research agenda on new business models for the twenty-first century. International Journal of Entrepreneurial Behavior \& Research 25: 353-75.

Kummitha, Rama Krishna Reddy. 2018. Entrepreneurial urbanism and technological panacea: Why Smart City planning needs to go beyond corporate visioning? Technological Forecasting and Social Change 137: 330-39. [CrossRef] 
Kummitha, Rama Krishna Reddy. 2019. Smart cities and entrepreneurship: An agenda for future research. Technological Forecasting and Social Change 149: 119763. [CrossRef]

Laitinen, Ilpo, and Roberta Piazza. 2020. Smart City Community Engagement Through Learning, Smart Innovation. Systems and Technologies 158: 177-80.

Le Dinh, Thang, Manh Chien Vu, and Ayi Ayayi. 2018. Towards a living lab for promoting the digital entrepreneurship process. International Journal of Entrepreneurship 22: 1-17.

Lee, SangJeong, Min Chulhong, Yoo Chungkuk, and Song Junehva. 2013. Understanding customer malling behavior in an urban shopping mall using smartphones. In Proceedings of the 2013 ACM Conference on Pervasive and Ubiquitous Computing Adjunct Publication (UbiComp '13 Adjunct). New York: Association for Computing Machinery, pp. 901-10.

Lima, Marcos. 2020. Smarter organizations: Insights from a smart city hybrid framework. International Entrepreneurship and Management Journal 16: 1281-300. [CrossRef]

Li, Wenjie, Du Wenyu, and Yin Jiamin. 2017. Digital entrepreneurship ecosystem as a new form of organizing: The case of Zhongguancun. Frontiers of Business Research in China 11: 5. [CrossRef]

Manjon, Antolin Miguel, Aouni Zineb, and Crutzen Nathalie. 2019. Green and Digital Entrepreneurship in Smart Cities. Paper presented at 17th IECER Conference, Utrecht, The Netherlands, October 16-18.

Manville, Catriona, Gavin Cochrane, Jonathan Cave, Jeremy Millard, Jimmy Kevin Pederson, Rasmus Kåre Thaarup, Andrea Liebe, Matthias Wissner, R. A. Massink, and Bas Kotterink. 2014. Mapping Smart Cities in the EU. Available online: https: / / www.narcis.nl/publication/RecordID/ oai:tudelft.nl:uuid:1fac0e18-8dd3-406d-86fe-ce1e6a22e90c (accessed on 25 May 2021).

Mittal, Shilpi, and Mahendra Sethi. 2018. Smart and Livable Cities: Opportunities to Enhance Quality of Life and Realize Multiple Co-benefits. In Mainstreaming Climate Co-Benefits in Indian Cities. Singapore: Springer, pp. 245-63.

Nam, Taewoo, and Theresa A. Pardo. 2011. Conceptualizing smart city with dimensions of technology, people, and institutions. Paper presented at the 12th Annual International Conference on Digital Government Research, College Park, MD, USA, June 12-15.

Nguyen, Quoc Toan, and Thi Nhu Dao. 2020. Smart urban governance in smart city 2020. IOP Conference. Series: Materials Science and Engineering 869: 022021. Available online: https://iopscience.iop.org/article/10.1088/1757-899X/869/2/022021/pdf (accessed on 6 June 2021).

Ninčević, Pašalić Ivana, Ćukušić Maja, and Jadrić Mario. 2021. Smart city research advances in Southeast Europe. International Journal of Information Management 58: 102127. [CrossRef]

Pacut, Agnieszka. 2020. Drivers toward social entrepreneurs engagement in Poland: An institutional approach. Administrative Sciences 10: 5. [CrossRef]

Paiva, Sara, Ahad Mohd Abdul, Tripathi Gautami, Feroz Noushaba, and Casalino Gabriella. 2021. Enabling Technologies for Urban Smart Mobility: Recent Trends, Opportunities and Challenges. Sensors 21: 2143. [CrossRef]

Pita, Mariana, Costa Joana, and Moreira Antonio Carrizo. 2021. Entrepreneurial Ecosystems and Entrepreneurial Initiative: Building a Multi-Country Taxonomy. Sustainability 13: 4065. [CrossRef]

Prakash, Alok. 2021. Smart Mobility Solutions for a Smart City. IEEE Potentials 40: 24-29. [CrossRef]

Purbasari, Ratih, Muttaqin Zaenal, and Sari Deasy Silvya. 2021. Digital Entrepreneurship in Pandemic Covid 19 Era: The Digital Entrepreneurial Ecosystem Framework. Review of Integrative Business and Economics Research 10: 1-114.

Richter, Chris, Kraus Sascha, and Syrjä Pasi. 2015a. The Smart City as an opportunity for entrepreneurship. International Journal Entrepreneurial Venturing 7: 211-26. [CrossRef]

Richter, Chris, Kraus Sascha, and Syrjä Pasi. 2015b. The shareconomy as a precursor for digital entrepreneurship business models. International Journal Entrepreneurship and Small Business 25: 18-35. [CrossRef]

Rodríguez Bolívar, Manuel Pedro. 2018. Governance models and outcomes to foster public value creation in smart cities. Scienze Regionali 17: 57-80.

Sahut, Jean-Michel, Iandoli Luca, and Teulon Frederic. 2019. The age of digital entrepreneurship. Small Business Economics 56: $1159-69$. [CrossRef]

Salkuti, Surender Reddy. 2021. Smart cities: Understanding policies, standards, applications and case studies. International Journal of Electrical and Computer Engineering 11: 3137-44.

Schiavone, Francesco, Appio Francesco Paolo, Mora Luca, and Risitano Marcello. 2020. The strategic, organizational, and entrepreneurial evolution of smart cities. International Entrepreneurship and Management Journal 16: 1155-65. [CrossRef]

Schulz, Thomas, Böhm Markus, Gewald Heiko, and Krcmar Helmut. 2021. Smart mobility-An analysis of potential customers' preference structures. Electron Markets 31: 105-24. [CrossRef]

Scornavacca, Eusebio, Francesco Paolone, Stefano Za, and Laura Martiniello. 2020. Investigating the entrepreneurial perspective in smart city studies. International Entrepreneurship and Management Journal 16: 1-27. [CrossRef]

Silva, Bhagya Nathali, Khan Murad, and Han Kijun. 2018. Towards sustainable smart cities: A review of trends, architectures, components, and open challenges in smart cities. Sustainable Cities and Society 38: 697-713. [CrossRef]

Smart City Indicators. 2019. Available online: https:/ / hub.beesmart.city/smart-city-indicators/ (accessed on 10 June 2021).

Song, Abraham K. 2019. The Digital Entrepreneurial Ecosystem-A critique and reconfiguration. Small Business Economics 53: 569-90. [CrossRef]

Spigel, Ben. 2015. The relational organization of entrepreneurial ecosystems. Entrepreneurship Theory and Practice 41: 49-72. [CrossRef] Sussan, Fiona, and Zoltan J. Acs. 2017. The digital entrepreneurial ecosystem. Small Business Economics 49: 55-73. [CrossRef] 
The Global Entrepreneurship and Development Institute. 2020. The Digital Entrepreneurial Ecosystem. Available online: https: / / thegedi.org/the-digital-entrepreneurial-ecosystem/ (accessed on 3 May 2021).

Tomor, Zsuzsanna, Przeybilovic Erico, and Leleux Charles. 2021. Smart governance in institutional context: An in-depth analysis of Glasgow, Utrecht, and Curitiba. Cities 114: 103195. [CrossRef]

Toppeta, Donato. 2010. The Smart City Vision: How Innovation and ICT Can Build Smart, "Livable", Sustainable Cities: The Innovation Knowledge Foundation. Available online: https://inta-aivn.org/images/cc/Urbanism/background\%20documents/Toppeta Report_005_2010.pdf (accessed on 30 April 2021).

Trencher, Gregory. 2019. Towards the smart city 2.0: Empirical evidence of using smartness as a tool for tackling social challenges. Technological Forecasting and Social Change 142: 117-28. [CrossRef]

Van der Hoogen, Anthea, Scholtz Brenda, and Calitz Andre. 2019. A Smart City Stakeholder Classification Model. 2019. Paper presented at Conference on Information Communications Technology and Society (ICTAS), Durban, South Africa, March 6-8.

Vinod, Kumar. 2020. Smart Environment for Smart Cities. In Smart Environment for Smart Cities. Edited by Kumar Vinod. Advances in 21st Century Human Settlements. Singapore: Springer.

World Bank. 2019. Urban Population (\% of Total Population). Available online: https://data.worldbank.org/indicator/SP.URB.TOTL. IN.ZS (accessed on 23 April 2021).

Yigitcanlar, Tan, Han Hoon, Kamruzzaman Md, Ioppolo Giuseppe, and Sabatini-Marques Jamile. 2019. The making of smart cities: Are Songdo, Masdar, Amsterdam, San Francisco and Brisbane the best we could build? Land Use Policy 88: 104187. [CrossRef]

Yudono, A., Dias Satria, and Angga Erlando. 2019. Toward Inclusive Development Through Smart Economy in Malang Regency. IOP Conference Series: Earth and Environmental Science 328: 012008. Available online: https://iopscience.iop.org/article/10.1088/1755 $-1315 / 328 / 1 / 012008 / p d f$ (accessed on 30 May 2021). [CrossRef]

Yun, Yeji, and Minhwa Lee. 2019. Smart City 4.0 from the perspective of open innovation. Journal of Open Innovation: Technology, Market, and Complexity 5: 92. [CrossRef]

Zaheer, Hasnain, Breyer Yvonne, and Dumay John. 2019. Digital entrepreneurship: An interdisciplinary structured literature review and research agenda. Technological Forecasting and Social Change 148: 119735. [CrossRef]

Zavratnik, Veronika, Podjed Dan, Trilar Jure, Hlebec Nina, Kos Andrej, and Stojmenova Duh Emilija. 2020. Sustainable and Community-Centred Development of Smart Cities and Villages. Sustainability 12: 3961. [CrossRef] 